Volume 17 Issue 3
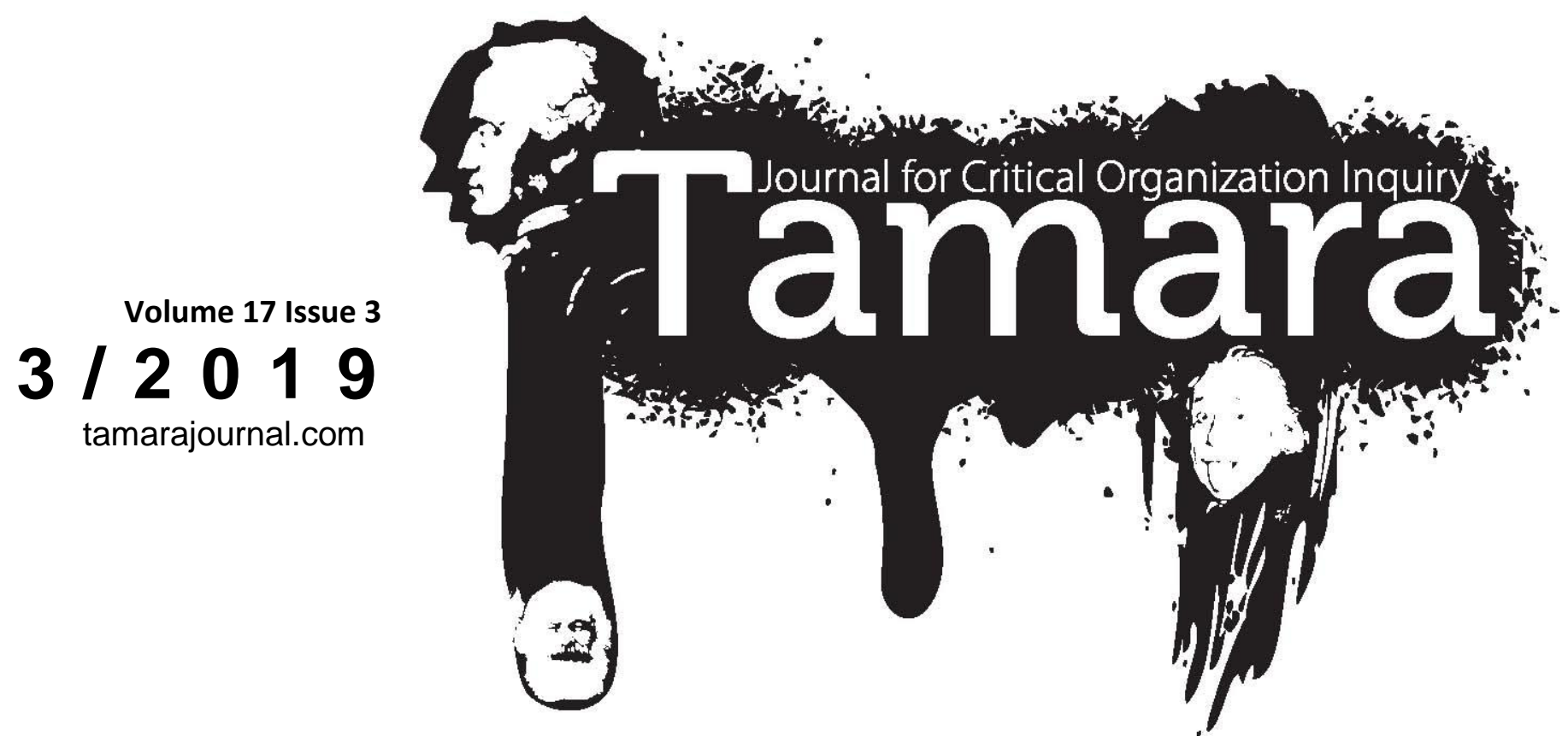

tamarajournal.com

\title{
Does neoliberalism's ethical consumer create more problems than she solves? A discussion of a neocommunitarian alternative
}

Klaus Brønd Laursen

Aarhus University, Denmark

Nikolaj Kure

Aarhus University, Denmark

\begin{abstract}
Keywords
ethical consumer

neoliberalism

neocommunitarism
\end{abstract}

discourse

\begin{abstract}
The ethical consumer occupies a significant position in the current capitalist system as the market-based answer to a whole range of negative externalities. Unfortunately, she has been proven to behave out of sync with her ethical values and thus has been taken apart by scholars as a mere myth. Yet, businesses and politicians continue to believe in her abilities. This, we argue, is not caused by them being blind to her failures but because the category of the ethical consumer represents an ideal solution in the neoliberal discourse that embraces the holy trinity of an unregulated market, personal emancipation and the freedom of choice. Unfortunately, the ethical consumer has turned out to be a poorly suited solution to the negative externalities as ecological and social critiques continue to emerge. In response, a neocommunitarian discourse seems to gain strength, replacing the neoliberal version of the market as a bifurcation point between customers and suppliers instead bringing together businesses and consumers in a new type of network formation overcoming the bifurcation between consumers and producers.
\end{abstract}

\section{Introduction}

In recent decades, ethical consumers have been casted as the ideal market-based solution to a range of collective problems, such as issues of sustainability, animal welfare and inequality (Jessop, 2002). Driven by ethical values, this type of consumer is believed to eliminate or reduce market externalities by demanding 'ethical' or 'sustainable' goods that do not incur hidden costs on society at large.

However, subjected to a closer scrutiny, the ethical consumer has been de-masked as a myth that emerges from faulty methods and ideologically-based expectations (Devinney, Auger, \& Eckhardt, 2010). Politicians and businesses may well operate on the premise that large parts of the consumer population consist of ethical consumers, yet thorough empirical 
evidence shows that while many consumers may have intentions of acting ethically, this is not reflected in their actual buying behaviour (Carrington, Neville, \& Whitwell, 2010; Chatzidakis, Hibbert, \& Smith, 2007; Padel \& Foster, 2005).

In this light, the current paper has two overall ambitions: 1) to understand why politicians and businesses continue to rely on the category of the ethical consumer to solve urgent collective problems when it is getting still more evident that this type of consumer is mythical, and 2) to discuss if alternative ways of understanding ethical consumption may be detected in contemporary commerce. Thus, our general ambition is to add to the growing field of literature on sustainable consumption and circular economy to suggest that effective change needs to move beyond the individual level and reach into a systemic and discursive sphere (Camacho-Otero, Boks, \& Pettersen, 2018; Grabs, Langen, Maschkowski, \& Schäpke, 2016).

The article has four sections. In the first section, we observe how the ethical consumer is identified in the vast field of consumer studies. Following a constructivist logic, we carry out a second order observation (Andersen, 2003; Moeller, 2017) that aims to describe how the ethical consumer emerges as a social phenomenon when observed by consumer scholars. This implies that we do not attempt to observe the ethical consumer as such, rather we try to observe how the category of the ethical consumer is constructed by someone else (Moeller, 2017, p. 30).

In the second section, we discuss if the category of the ethical consumer can be seen as a component of justification that serves to mitigate the various types of ecological and social critiques currently directed towards the capitalist system. Inspired by Boltanski and Chiapello's (1999/2005) analysis of how capitalism systematically transforms itself by absorbing critique that addresses systemic failures in the capitalist system, we argue that in an environment where negative externalities - market operations where the costs of individual actors are incurred on society at large - are becoming still more visible, capitalism increasingly needs a justificatory mechanism to mobilise the masses to maintain faith in itself as the best available system of allocating goods. Our contention is that the category of the ethical consumer serves this exact purpose in a distinct neoliberal discourse.

In the third section, we argue that the ethical consumer shows signs of a justificatory crisis. Currently, economic externalities accumulate into an array of severe ecological problems (global warming, micro plastics in oceans, etc.), social problems in the shape of inequality (Piketty, 2014) and precariousness on labour markets (Standing, 2011, 2014). This raises the question of whether or not the category of the ethical consumer is an adequate answer to the challenges posed.

Based on the contention that this is not the case, the fourth section attempts to illustrate how we are currently witnessing the formation of an alternative market configuration that ceases to rely on the ethical consumer but rather puts its emphasis on a joint consumer/producer responsibility. We argue that this move is made meaningful in a distinct neocommunitarian discourse that challenges the key tenets of neoliberalism. The fourth section is based on a case study of the Danish agricultural entity Gram Slot.

\section{The ethical consumer}

The category of the ethical consumer has attracted a wealth of scholarly attention in recent decades. The ethical consumer primarily occupies a prominent role in the field of consumer studies where the figure is used as a theoretical construct to study how consumers shape their behaviour in accordance with inner values (Carrington et al., 2010; Chatzidakis, Kastanakis, \& Stathopoulou, 2016; De Pelsmacker, Driesen, \& Rayp, 2005; Shaw, Shiu, \& Clarke, 2000; Szmigin \& Carrigan, 2005). This conceptualisation is echoed in market research (Ipsos-Mori, 2016) and rural studies (Padel \& Foster, 2005) where it is applied to study how businesses may orient their sales strategies towards the fulfilment of ethical consumers' desires (Carbone, Gaito, \& Senni, 2009).

Across these studies, the ethical consumer emerges as a social phenomenon with four core characteristics. First, the values of the ethical consumer are believed to be of a stable and endogenous nature. They rest within the consumer and are only modified with great difficulty (Devinney et al., 2010; Vermeir \& Verbeke, 2006). Second, the inner values are expected to direct the behaviour of the ethical consumer (Vermeir \& Verbeke, 2006). The ethical consumer is essentially believed to operate following a causal logic where consumption behaviour linearly reflects endogenous values. Third, ethical consumption choices are the result of an individual decision process. While this may seem self-evident, it does have the effect of stimulating studies of a psychological slant (as opposed to a sociological one) that tend to ignore or render marginal the social or societal dimensions in individual decision-making processes (Chatzidakis et al., 2007; De 
Pelsmacker et al., 2005). Fourth, as producers and consumers have two diametrically-opposed interests (Carrigan \& Attalla, 2001), the ethical consumer is posited as producers' opposite number in a binary structured market place. Thus, only one means of dialogue seems possible, namely, the one created when demand information is transmitted to producers by the medium of the market.

As it appears, the ethical consumer shares many characteristics with the rational consumer found in neoclassic economic thinking (Choudhury, 1995). But, where rational consumers operate with the purpose of fulfilling various needs, the ethical consumer moves beyond this. Thus, the behaviour of ethical consumers is not simply a form of bounded rationality with choices restricted by exogenous factors such as price or quantity; rather ethical consumption emerges as meaningful because of consumers' endogenous values, hence the very label 'ethical'.

If we believe that the consumer population largely consists of 'ethical consumers', there is no reason for businesses to concern themselves with issues of social responsibility. In Milton Friedman's words their task is simply to provide the goods that allow consumers to produce their own satisfaction (Friedman, 1970). However, this argumentation seems to be on thin ice as ethical consumers continue to display a so-called attitude-behaviour gap with regard to their willingness to actually behave according to their intentions (Boulstridge \& Carrigan, 2000; Carrington et al., 2010; Padel \& Foster, 2005). This observation has triggered a number of research currents that view the ethical consumer in a critical light. These currents may be separated into three groups: an empirical, a theoretical, and a methodological critique. The first group consists of studies that examine the actual relation between consumer intentions/values and behaviour. Drawing on the field of behavioural economics (Bray, Johns, \& Kilburn, 2010; Padel \& Foster, 2005; Shaw, Grehan, Shiu, Hassan, \& Thomson, 2005; Szmigin \& Carrigan, 2005), these studies confirm the general picture that actual consumer behaviour in most cases does not display the idealised relation between attitudes and behaviour as expected by proponents of ethical consumption. Instead, people's decisions seem largely to be founded on contextual factors. For example, noble intentions of always using a condom when having sex is often neglected when the actual act takes place under the influence of alcohol (Belk, Østergaard, \& Groves, 1998). Similarly, people may well support animal welfare when acting as politically-oriented citizens while the same people have no problem in actually eating meat (Schröder \& McEachern, 2004). As Holt ironizes, it is no rarity to see ethically-oriented people proudly drive their electricity-fuelled Toyota Priuses to the airport to engage in long distance overseas flights (Holt, 2012, p. 240).

The empirical problems related to the ethical consumer have stimulated a theoretically-oriented stream of critique that discusses the assumptions that underpin the category of the ethical consumer (Caruana, Carrington, \& Chatzidakis, 2015). For example, the ethical consumer has been criticised for resembling an idea of consumption that does not adhere to the everyday practices of the vast majority of consumers (Adams \& Raisborough, 2010). To most consumers abstract ethical ideals are far removed from everyday practises of consumption (Devinney et al., 2010, p. 62) and thus the ethical consumer depicts an idealisation of behaviour rather than an accurate description of behaviour (ibid 116).

Finally, and in close connection to the theoretical critique, we find a methodologically-oriented critique that discusses how the ethical consumer reflects the methods used to observe ethical consumption. Thus, many of the methods applied rely on a linear perception of the relationship between values and behaviour, giving rise to the observation of results that mime this linearity. Furthermore, the applied research instruments - be it surveys or individual or group interviews - are criticised for suffering from social desirability, i.e. they are influenced by linguistic and/or contextual factors that may result in a confirmation of the sought for effects (Devinney et al., 2010, pp. 56-59).

Despite these forms of critiques, the ethical consumer continues to be reproduced in researchers' and politicians' mindsets and theories (Chatzidakis et al., 2016; Johnstone \& Tan, 2015; Shaw, McMaster, \& Newholm, 2015); this has led some scholars to argue that the ethical consumer is nothing but at myth (Devinney et al., 2010). In the following, however, we attempt to move the discussion beyond whether or not the ethical consumer can be catagorized as a mere myth. In particular, we are interested in understanding what kind of function the ethical consumer occupies in the capitalist system given that the idea has not been broadly rejected as a myth. Our starting point is Boltanski and Chiapello's (1999/2005) proposition that capitalism systematically justifies itself by absorbing critique that addresses systemic failures in the capitalist system. Incidentally, our contention is that the category of the ethical consumer can be seen as a component of justification that serves to mitigate the various types of ecological and social critique that are currently directed towards the capitalist system. 


\section{The ethical consumer as a component of justification?}

As mentioned, this section draws on the assumption that capitalism needs to incorporate a justificatory dimension to mobilise people to support and take part in its insatiable processes (Boltanski \& Chiapello, 1999/2005, p. 485ff.). The attempt is to show how the current configuration of capitalism, namely what has been coined neoliberalism (Harvey, 2005/2007), installs the category of the ethical consumer to handle the growing amount of systemic critiques directed towards the capitalist system, particularly the critique that capitalism in its current form is unable to handle negative externalities such as climate change. In order to advance this argument, we start by describing the main tenets of neoliberalism and then show how the ethical consumer emerges as a specific form of justification within this frame.

It is safe to say that capitalism in the 20th century has been shaped around two major market configurations: Keynesianism and neoliberalism. Keynesianism had its heyday during the time of Roosevelt's New Deal and the postWWII establishment of western welfare states. However, in the 1970s, Keynesianism experienced a number of severe problems, particularly concerning stagflation, which paved the way for neoliberalism. Neoliberalism, as Foucault has argued, is more than a simple theory about the ideal organisation of the market. In his view, neoliberalism - and Keynesianism for that matter - is a general discursive formation that puts in place the mere conditions for thought, analysis and imagination (Foucault, 2010, p. 219).

Originally, neoliberalism found its justification in promising a radical liberation of the individual (Friedman, 1962/1982). In doing so, neoliberalism imported the powerful moral concepts of dignity, individual freedom and free choice from political theory into the economic paradigm (Harvey, 2005/2007). Deregulations were to deliver the promised land of individual emancipation in the prevailing capitalist order (Jessop, 1998, 2002), a promise that soon achieved such widespread acceptance that by the end of the Cold War, any alternatives to the capitalist-liberalist world order were close to unthinkable (Fukuyama, 1992). This even included traditionally Keynesian-oriented groups, such as the US Democrats and the British Labour Party having embraced the neoliberal ideas (Harvey, 2005/2007).

By setting the market free and thus emancipating consumers, the neoliberal discourse introduced the expectation that innovations will emerge spontaneously (Jessop, 2002, p. 462). With no governmental ties, the market will not be faced with arbitrary political demands, and individual self-governance will leave no constraints on the will and imagination of market operators. As a result, the market should be capable of meeting any thinkable demand (Schumpeter, 1943/2010; von Mises, 1949/1998).

These expectations are mirrored in a particular image of the consumer. In the neoliberal logic, individual choice and freedom are given shape in consumers' ability to produce their own satisfaction by combining market goods with the household's own time and logic (Michael \& Becker, 1973). Thus, the neoliberal version of the consumer is not simply a partner of exchange, as is the case in classical liberalism, but rather an entrepreneur who creates her own individual satisfaction regardless of traditional class boundaries (Foucault, 2010, p. 226). For example, a blue-collar worker may buy an Audi to tell a story of social improvement or a middle-class manager may support a traditional working-class football team to reconnect with his family's values and rituals - both stories that find their justifications in the overarching narrative of individualism (Boltanski \& Chiapello, 1999/2005, p. 532; Jensen, 2009).

The conceptualisation of homo economicus as an entrepreneur provides a common ground on which workers and capital owners can meet. Capital owners benefit from the flexibility and self-governance of employees and consumers (Sennett, 2006), while workers now have an opportunity to see themselves as emancipated individuals (Willmott, 1993). In consequence, whenever new market problems occur, the innovative energies released through the emancipation of the individual combined with the free circulation of the market should secure that somewhere someone has the resources to come up with an adequate solution.

However, the existence of market externalities poses a fundamental risk to this logic. In particular, the prevalent ecological critique of the neoliberal market configuration (Beck, 1986/1992; Chiapello, 2014) challenges the contention that the market is capable of handling ecological problems that transfer costs from individual business actors to society at large. To deal with this problem, the neoliberal market configuration has developed two sets of answers: First, the market responds to the new ecological dangers by producing goods that minimise the incurrence of costs on society at large; something that has resulted in a myriad of labels promising everything from better animal welfare, more sustainable production to social rights of workers, etc. By producing such 'ethical' or 'sustainable' goods, consumers' underlying 
concerns have been commodified into desirable objects (Boltanski \& Chiapello, 1999/2005, p. 441; Boltanski \& Thévenot, 1991/2006, p. 199).

Second, and crucially, the conceptualisation of the consumer has also been changed. As any other goods 'sustainable' or 'ethical' goods need a desirer - and who is more equipped to desire ethical products than the ethical consumer? The ethical consumer is the consumer who accepts that it is primarily the responsibility of the individual to handle the ecological problems produced on the market. However, the ethical consumer is also engaged in the production of the prime product pursued in late capitalist modernity: individual satisfaction. The result of this combination is that the market can be trusted to handle the ecological critique because the key component in satisfying the ethical demand is not only located in the production but also within the consumer herself. For instance, the consumption of organic carrots may be combined with the knowledge that they are not associated with $\mathrm{CO} 2$-emissions, resulting in the creation of a particular consumer satisfaction. This means that the category of the ethical consumer both appears as a consumer model to whose desires the market responds but it also provokes a change to the nature of the market itself, not due to the direct actions of ethical consumers but because the market restructures itself based on the expectation that ethical consumers exist. This seemingly tautological description reveals probably the most central characteristic of the ethical consumer: She functions as a key component in what observers of the creation of markets has described as performativity (Callon, 1998; Esposito, 2013). Only if we believe that the ethical consumer is capable of handling externalities, can the neoliberal version of the free-market system mobilise support. Thus, it seems that the ethical consumer is capitalism's way of handling the issue of externalities within the current neoliberal discourse formation. Not only does the ethical consumer solve the problem of how to deal with externalities, she also confirms the neoliberal argument in favour of an unregulated market as the best solution to such problems. In this light, we contend that the neoliberal version of capitalism to an increasing degree needs the category of the ethical consumer to justify itself when faced with the growing ecological critique currently witnessed. Without the notion of the ethical consumer, the production of externalities would pose such a significant threat to the current economic system that its survival would be endangered.

\section{The ethical consumer in crisis?}

The main question is now: Have we reached a point where the ethical consumer no longer functions as a justification to the current capitalist configuration? In the neoliberal narrative, negative externalities are safely handed by the ethical consumer but it has become increasingly clear that actual evidence tells a different story. As it is, we currently witness a process in which economic externalities are accumulating into an array of severe ecological problems (global warming, micro plastics in oceans, etc.) and social problems in the shape of inequality (Piketty, 2014) and precariousness on labour markets (Standing, 2011, 2014). On this basis alone, it seems a fair conclusion that the category of the ethical consumer is not an adequate answer to the challenges posed. In theory, the ethical consumer should be able to handle these issues, for instance by demanding products produced under safe and secure working conditions, but this does not seem to happen in the real world, at least not to any substantial extent. In fact, ethical consumers may even play an active part in the production of externalities, for instance by buying organic fruit and vegetables wrapped in polystyrene or by buying bottled water that brands itself as environmentally friendly while in fact having an immense negative environmental impact (Holt, 2012). This indicates that complex ecological issues simply slip through the net of the neoliberal market constellation and this even to the extent that it risks putting the market itself in danger.

If this diagnosis is correct, the neoliberal market discourse seems to face a severe legitimization crisis. If the key component of its justification, the category of the ethical consumer, does not provide evidence that she is capable of dealing with the key problematic, the issue of externalities, then the entire neoliberal version of capitalism may be cast in doubt.

\section{Another type of capitalism: Gram Slot?}

French philosophers Michel Foucault and Jacques Derrida remind us that any discourse needs a counter-discourse to exist (Derrida, 1967/1976, p. 144f. ; Foucault, 1976/1998, p. 95). Thus, the question is not if but where to search for alternative articulations of capitalism that approach the ecological critique in new ways.

The literature on Alternative Food Networks (AFN) may provide a starting point as it explicitly aims at breaking with the dominant neoliberal market configuration (Lamine, 2005; Laursen \& Noe, 2017; Marsden, 2000; Renting, Marsden, \& Banks, 2003). An interesting case from this literature is the Danish agricultural firm Gram Slot (Gram Castle) (Laursen \& 
Noe, 2017; Laursen, Noe, \& Kjeldsen, 2015). As the Danish agricultural sector represents one of the most industrialised and bulk-oriented food regimes in the world (Kærgård \& Dalgaard, 2016), alternative initiatives like Gram Slot are forced to enact a radically different market understanding in order to avoid conventionalisation and thus turn into yet another company adhering to the neoliberal market logic (Buck, Getz, \& Guthman, 1997; Guthman, 2003). In a Danish context, Gram Slot truly represents an alternative to the conventional way of doing agricultural business. Not only does it represent a different approach to production but, perhaps more importantly, it demonstrates a significantly different approach to understanding how the market is configured in the capitalist order.

Gram Slot is studied as part of the Core Organic project HealthyGrowth (HealthyGrowth) where it is one of 18 case studies. Each case is described by means of a template that consists of more than 130 descriptive and analytical questions. Empirically, the Gram Slot case study (Laursen et al., 2015) relies on six qualitative interviews (including three interviews with the owners and one with a central person from the REMA 1000 supermarket chain ) and a comprehensive archive of sources that range from documents from the local municipality, newspaper articles, television programs, $\mathrm{PhD}$ theses, scientific articles, trade journal articles, YouTube and Facebook ${ }^{\mathrm{i}}$.

Gram Slot, located in the southern part of Denmark, was acquired by its current owners in 2007, bringing with them a distinct ambition to revitalise the then run-down castle. Central elements in this process included the conversion of the production facilities into organic farming and the opening of the castle to the public. This required a thorough restoration of the premises, which again required financing. The process was scheduled to begin in 2008 but the financial crisis in 2007-2009 meant that loans dried up, particularly in the agricultural sector. An alternative solution was found in the strategic partnership with the Norwegian discount supermarket chain REMA 1000, which provided new capital in exchange for a 20-per cent ownership of the Gram Slot shares. In a Danish context, this step was unusual as it broke with a century-long principle of self-ownership in the agricultural sector. However, the strategic partnership was set up, and Gram Slot now operates a business model that combines cultural activities, dissemination and organic farming in an effort to develop a sustainable all-inclusive approach to environmental issues (Laursen et al., 2015).

If the owners of Gram Slot were informed by a neoliberal logic, i.e. if it was assumed that a particular percentage of consumers share a set of ethical values, the practical consequence would be to identify and target this predefined consumer group, accommodating their 'ethical demand'. Yet this was not the case at Gram Slot. In fact, prior to the process that led to the partnership with REMA 1000, a market analysis identified a high-end supermarket chain as the ideal match for Gram Slot. High-end supermarkets offer the most complete selection of organic or 'ethical' products thus providing the most rational outlet for Gram Slot. However, this recommendation was flatly dismissed by the owners, who believed that organic produce should extend well beyond luxury niche products for well-off people. Instead, the partnership with the discount chain REMA 1000 was initiated with the explicit purpose of promoting accessible organic food to ordinary people.

This move reflects an explicit intention of creating a dialogical relationship with consumers. Instead of trying to match the preferences of high-end consumers, Gram Slot views ordinary consumers as reflective beings with whom one can engage in a dialogical process and thus promote the idea of sustainability. For example, this is reflected in Gram Slot's open-door policy where visitors have free access to the cowshed and can talk to staff members while looking at the animals. Another interesting example of this style of thinking can be found in the extensive use of Facebook. On this platform, Gram Slot is actively engaged in a dialogue with the greater public, ranging from answering simple questions, advertising events and products, searching for new employees and addressing critique. Especially in relation to critical comments, Gram Slot's Facebook wall demonstrates the effect of a reflexive and dialogical way of thinking. Not only is critique met openly in dialogue, often members of the public engage in the discussion creating a unique space for deliberation on issues that in many other contexts tend to be confined to a brief complaint and related answer or apology.

In general, Gram Slot consumers are not seen as some who attempt to actualise their stable endogenous values. Instead, dialogue and openness are seen as elements in an interactive process in which a common understanding of organic production is co-produced. This idea is underpinned by the belief that values are not simply something that belong to the individual - rather they emerge as the result of active engagement in a community. Therefore, it is not surprising to find that the owners of Gram Slot view the surrounding society as a central player in the constitution of the values that inform the operation of Gram Slot. For example, the owners actively engage in the public debate on agriculture and 
sustainable conversion. They believe that by setting an example of profitable large-scale organic production, they help promote a change in the agricultural community and society in general. In this sense, Gram Slot is an active player in creating a prosperous local community in a rural part of Denmark otherwise threatened by degrowth and depopulation. On this backdrop, it seems fair to say that Gram Slot's way of relating to consumers and the public is informed by a line of thinking that sees the bifurcated consumer/business relationship of the neoliberal discourse replaced by a processual understanding of the market as a reciprocal place of interaction.

\section{A neocommunitarian discourse?}

The insights sketched above beg the question of how to conceptualise this radically different way of approaching and constructing the market. As we shall argue, Gram Slot seems to reflect a broader movement that gains its critical potential from perhaps the most significant of the contemporary critiques of neoliberalism, i.e. neocommunitarism.

Like neoliberalism, neocommunitarism was initially articulated as a philosophic argument. Central thinkers in the neocommunitarism tradition include Hannah Arendt (1958/1998), Alistair McIntyre (1981/2007, 1999) and Charles Taylor (1991). They criticized central philosophical neoliberalist ideas - for instance the assumption that the individual is capable of acting in an atomised, rational self-interested manner (Davies, 2012) - and instead developed a view on human nature as essentially social; hence the label 'communitarian'. In this view, a neocommunitarian market configuration emphasizes the role of partnerships between businesses, the state and community organisations (Jessop, 2002, p. 436).

Again, like neoliberalism, the communitarian thoughts left the philosophic circles and migrated into policy making, for instance exemplified in the growing number of public welfare institutions in which volunteers play an important role (Sløk \& Villadsen, 2008). However, the market for private businesses has also seen the emergence of operators who seem to dismiss von Mises' (von Mises, 1949/1998) strong belief in the consumer as the principal first mover. These organizations seem to act in accordance with their own values, motivations and ideas (Adams \& Raisborough, 2010; Binkley, 2008; Caruana, 2007a, 2007b). The Alternative Food Networks (AFN) (Jarosz, 2008; Renting et al., 2008; Renting, Schermer, \& Rossi, 2012) and Community Supported Agriculture (CSA) (Cox et al., 2008; Thompson \& Coskuner-Balli, 2007) are significant private market actors that rely on the idea that businesses and consumers share a mutual interest in promoting sustainable food production (as opposed to a neoclassic demand-supply logic). Thus, we appear to see the initial signs of the development of a neocommunitarian discourse that offers a new general style of thought, analysis and imagination as to how the relation between market operators and society may be construed. When observing Gram Slot, we find that at least four central features of the neocommunitarian discourse is prevalent:

First, at Gram Slot individual attitudes are assumed to be shaped by social norms rather than resembling endogenous values. This idea is most significantly put forward in the philosophical understanding of communitarism (MacIntyre, 1981/2007; Taylor, 1991) but may also be traced to actual market operators, for example AFN and Community Supported Agriculture (CSA). In AFN, an important feature is the "civic engagement into shaping public opinion, culture, institutions and policies by communication, lobbying and political activism” (Renting et al., 2012, p. 300). This is echoed in CSA where members agree to pay farmers for a share of their produce prior to the season and, in many cases, also accept to provide working hours on the farm, leaving plenty of opportunities to talk and influence each other's opinions towards producer-consumer relationships (Cox et al., 2008).

Second, values are not expected to translate into behaviour in a linear fashion. When values are seen as exogenous, they are always already social and may thus never work in an entirely linear fashion. This is what we find in Gram Slot's devotion to acting as an ambassador for organic and sustainable farming. Instead, the relationship between values and behaviour is a much more circular or reflective one, reflecting that market behaviour is the results of dialogues and communication between market participants. This may be why communication between the involved partners in CSA is of key importance to the success of the initiative (Cox et al., 2008).

Thirdly, the strong individualism of neoliberalism is replaced with a focus on the individual as a social being. The restoration of the castle and the devotion to taking responsibility for future generations are examples of this point. In the neocommunitarian discourse, individuals achieve much of their human character from the social relations in which they engage. Not only are values formed socially, they are also central to the ability to engage in relations with other humans (Arendt, 1958/1998). Again, AFN and CSA may serve as illustrations. Neither of these initiatives would be anything but yet another form of a supply and demand relation were it not because of the sociality unfolded in and around these 
arrangements. Especially in CSA, the social interaction plays an important role in constituting the very nature of these initiatives, thereby creating their uniqueness and market appeal.

Finally, in the neocommunitarian discourse, the bifurcated understanding of the market as split between the interests of consumers versus that of businesses is rejected in favour of an image of the market as mutually constituted by businesses, consumers, policy makers, etc. Gram Slot, for example, does not rely on a bifurcated understanding of the market as the relationship with consumers is of central importance to this type of business.

\section{Conclusion}

This article is motivated by the stark contrast between, on the one hand, the persistent belief in the category of the ethical consumer as the market-based solution to ecological problems and, on the other, the strong empirical evidence that actual consumers do not act in accordance with the ethical consumer ideal. Why has the ethical consumer not been rejected as a theoretical construct when it is quite clear that she is best described as a myth? In this paper, we have argued that this insistence may be explained by means of Boltanski and Thévenot's concept of justification (Boltanski \& Thévenot, 1991/2006). In this understanding, the ethical consumer does not serve as a representation of actual consumer behaviour; rather she functions as a justificatory category within the distinct neoliberal version of capitalism. The analysis thus lends support to the insight that capitalism survives due to a remarkable ability to absorb critique turning it into productive elements of the system itself (Boltanski \& Chiapello 1999/2005). This, consequently, implies that markets are always in the making as new critiques fosters new solutions, which in turn are prone to new critiques. One of these new solutions has the shape of a neocommunitarian market configuration, which articulates the market as a place of shared responsibility and dialogue. We have illustrated this alternative discourse with the case of Gram Slot.

It is our contention that the paper generates three points of reflection: First, if we are right that the ethical consumer functions as a justificatory element in the neoliberal discourse, the most likely scenario is that decision-makers will continue to rely on this category, despite the growing body of evidence that points to flaws in this particular solution. Unless we are to abandon the neoliberal market logic entirely, we might even expect that the ethical consumer will be evoked even more rigorously in the face of growing environmental and climate problems. To question the ethical consumer is to jeopardise the very logic of the current discourse formation, and if we are not ready to do this, the likely result is that even more emphasis will be placed on the ethical consumer to correct market failures. In this sense, the neoliberal discourse is reproduced through a constant production of contradictions that call for new solutions that are formulated within the constraints of the inner logic of the discourse.

Second, the change from a bifurcated to a reciprocal market perception resembles a network that has no middle, end or beginning but displays multiple entryways. Perhaps, then, we are facing a rhizome (Deleuze \& Guattari, 1980/2013). An indication is the ceaseless effort to establish connections between a myriad of semiotic elements such as consumers, visitors, business relations, the municipality, etc. The rhizomic nature of the neocommunitarian discourse highlights how it will make no sense for neither consumers nor producers to expect that the other will act as the designated first mover in any market change. Instead, as the consumer's preference cannot be known from a distance, one has to join them and share their experience (Morgan, 1986/2006, p. 89). Consequently, change is more likely to appear in a process formed by reciprocal steps than one based on a causal supply and demand logic. A new product might be initiated by a producer who will see the product connect to one of the many rhizomic lines that make up the discourse. Rather than holding back and waiting until the right demand is articulated, the product is expected to connect and thereby actualise an already present line and hopefully experience success. Chances are taken but never in complete blindness as the rhizomic lines are what allows the change to emerge in the first place.

Third, neocommunitarism will most likely produce its own contradictions. Even the most idealistic discourse is by nature constituted through what it excludes. Perhaps we already see traces of this in the shape of so-called 'defensive localism' where the inclusion in the network is based on an exclusion (Winter, 2003) and where new forms of domination are thus put in place. This shows that the neocommunitarian discourse also contains its own blindness. Where the neoliberal discourse proved blind to the inability of the ethical consumer to solve the ecological critique, the neocommunitarian discourse will most likely prove blind to these exclusive mechanisms. Its basic assumption is that we are all included in the rhizomic nature of the discourse but this is by definition impossible. The implication is that new ideas will always be judged in relation to the basic assumption of the neocommunitarian discourse: the good of the 
community (Cruz, Beck, \& Wezel, 2017). To what extent this leaves a useful room for individual initiatives is an open question but a potential conflict is thinkable in consideration of the overarching narrative of individualism (Boltanski \& Chiapello 1999/2005).

\section{Acknowledgements}

The authors would like to thank Egon Noe, Gorm Harste and Steffen Roth as well as the reviewers of Tamara for constructive comments on earlier versions of the article.

\section{References}

Adams, M., \& Raisborough, J. (2010). Making a difference: ethical consumption and the everyday. The British Journal of Sociology, 61(2), 256-274. doi:10.1111/j.1468-4446.2010.01312.x

Andersen, N. Å. (2003). Discoursive Analytical Strategies: Understanding Foucault, Koselleck, Laclau, Luhmann. Bristol: The Policy Press.

Arendt, H. (1958/1998). The Human Condition. Chicago: University of Chicago Press.

Beck, U. (1986/1992). Risk Society. Towards a New Modernity. London: Sage Publications.

Belk, R. W., Østergaard, P., \& Groves, R. (1998). Sexual consumption in the time of AIDS: A study of prostitute patronage in Thailand. Journal of Public Policy \& Marketing, 17(2), 197-214.

Binkley, S. (2008). Liquid consumption: Anti-consumerism and the fetishized de-fetishization of commodities. Cultural Studies, 22(5), 599-623.

Boltanski, L., \& Chiapello, E. (1999/2005). The New Spirit of Capitalism. London: Verso.

Boltanski, L., \& Thévenot, L. (1991/2006). On Justification: Economies of Worth. Princeton \& Oxford: Princeton University Press.

Boulstridge, E., \& Carrigan, M. (2000). Do consumers really care about corporate responsibility? Highlighting the attitude-behaviour gap. Journal of Communication Management, 4(4), 355-368.

Bray, J., Johns, N., \& Kilburn, D. (2010). An exploratory study into the factors impeding ethical consumption. Journal of Business Ethics, 98(4), 597-608.

Buck, D., Getz, C., \& Guthman, J. (1997). From farm to table: The organic vegetable commodity chain of Northern California. Sociologia Ruralis, 37(1), 3-19.

Callon, M. (1998). Introduction: The Embeddedness of Economic Markets in Economics. In M. Callon (Eds.), The Laws of the Markets (Vol. 46, pp. 1-57). Oxford: Blackwell Publishers.

Camacho-Otero, J., Boks, C., \& Pettersen, I. (2018). Consumption in the circular economy: A literature review. Sustainability, 10(8), 1-25.

Carbone, A., Gaito, M., \& Senni, S. (2009). Consumer attitudes toward ethical food: evidence from social farming in Italy. Journal of Food Products Marketing, 15(3), 337-350.

Carrigan, M., \& Attalla, A. (2001). The myth of the ethical consumer-Do ethics matter in purchase behaviour? Journal of Consumer Marketing, 18(7), 560-578.

Carrington, M. J., Neville, B. A., \& Whitwell, G. J. (2010). Why ethical consumers don't walk their talk: Towards a framework for understanding the gap between the ethical purchase intentions and actual buying behaviour of ethically minded consumers. Journal of Business Ethics, 97(1), 139-158.

Caruana, R. (2007a). Morality and consumption: Towards a multidisciplinary perspective. Journal of Marketing Management, 23(3-4), 207-225.

Caruana, R. (2007b). A sociological perspective of consumption morality. Journal of Consumer Behaviour, 6(5), $287-304$.

Caruana, R., Carrington, M. J., \& Chatzidakis, A. (2015). Beyond the Attitude-Behaviour Gap: Novel Perspectives in Consumer Ethics: Introduction to the Thematic Symposium. Journal of Business Ethics, 136(2), 215-218.

Chatzidakis, A., Hibbert, S., \& Smith, A. P. (2007). Why people don't take their concerns about fair trade to the supermarket: The role of neutralisation. Journal of Business Ethics, 74(1), 89-100.

Chatzidakis, A., Kastanakis, M., \& Stathopoulou, A. (2016). Socio-cognitive determinants of consumers' support for the fair trade movement. Journal of Business Ethics, 133(1), 95-109.

Chiapello, E. (2014). Capitalism and Its Criticisms. In P. Du Gay \& G. Morgan (Eds.), New Spirits of Capitalism?: Crises, Justifications, and Dynamics. Oxford: Oxford University Press. 60-82. 
Choudhury, M. A. (1995). Ethics and economics: a view from ecological economics. International Journal of Social Economics, 22, 61-80.

Cox, R., Holloway, L., Venn, L., Dowler, L., Hein, J. R., Kneafsey, M., \& Tuomainen, H. (2008). Common ground? Motivations for participation in a community-supported agriculture scheme. Local Environment, 13(3), $203-218$.

Cruz, M., Beck, N., \& Wezel, F. C. (2017). Grown Local: Community Attachment and Market Entries in the Franconian Beer Industry. Organization Studies, 39(1), 47-72. doi:10.1177/0170840617695357

Davies, W. (2012). The emerging neocommunitarianism. The Political Quarterly, 83(4), 767-776.

De Pelsmacker, P., Driesen, L., \& Rayp, G. (2005). Do consumers care about ethics? Willingness to pay for fair-trade coffee. Journal of Consumer Affairs, 39(2), 363-385.

Deleuze, G., \& Guattari, F. (1980/2013). A Thousand Plateaus: Capitalism and Schizophrenia. London: Bloomsbury Publishing.

Derrida, J. (1967/1976). Of Grammatology (G. Spivak, Trans.). Baltimore \& London: Johns Hopkins University Press.

Devinney, T. M., Auger, P., \& Eckhardt, G. M. (2010). The Myth of the Ethical Consumer. Cambridge \& New York: Cambridge University Press.

Esposito, E. (2013). The structures of uncertainty: performativity and unpredictability in economic operations. Economy and Society, 42(1), 102-129.

Foucault, M. (1976/1998). The Will to Knowledge: The History of Sexuality Vol. I. New York: Pantheon Books

Foucault, M. (2010). The Birth of Biopolitics: Lectures at the Collège de France, 1978-1979 (M. Senellart, F. Ewald, A. Fontana, \& G. Burchell, Trans.). Basingstoke: Palgrave Macmillan Basingstoke.

Friedman, M. (1962/1982). Capitalism and Freedom. Chicago: University of Chicago Press.

Friedman, M. (1970). The Social Responsibility of Business is to Increase its Profits. New York Times, September 13.

Fukuyama, F. (1992). The End of History and the Last Man. London: Penguin Books.

Grabs, J., Langen, N., Maschkowski, G., \& Schäpke, N. (2016). Understanding role models for change: a multilevel analysis of success factors of grassroots initiatives for sustainable consumption. Journal of Cleaner Production, 134, 98-111.

Guthman, J. (2003). Fast food/organic food: Reflexive tastes and the making of 'yuppie chow'. Social \& Cultural Geography, 4(1), 45-58. doi:10.1080/1464936032000049306

Harvey, D. (2005/2007). A Brief History of Neoliberalism. Oxford: Oxford University Press.

HealthyGrowth. Retrieved from http://projects.au.dk/healthygrowth/

Holt, D. B. (2012). Constructing sustainable consumption from ethical values to the cultural transformation of unsustainable markets. The Annals of the American Academy of Political and Social Science, 644(1), 236-255.

Ipsos-Mori. (2016). Retrieved from https://www.ipsos-mori.com/researchpublications/researcharchive/3408/Publicviews-on-ethical-retail.aspx

Jarosz, L. (2008). The city in the country: Growing alternative food networks in metropolitan areas. Journal of Rural Studies, 24(3), 231-244.

Jensen, A. F. (2009). Projektsamfundet. Aarhus: Aarhus Universitetsforlag.

Jessop, B. (1998). The rise of governance and the risks of failure: the case of economic development. International Social Science Journal, 50(155), 29-45.

Jessop, B. (2002). Liberalism, neoliberalism, and urban governance: A state-theoretical perspective. Antipode, 34(3), 452472. doi:10.1111/1467-8330.00250

Johnstone, M.-L., \& Tan, L. P. (2015). Exploring the gap between consumers' green rhetoric and purchasing behaviour. Journal of Business Ethics, 132(2), 311-328. doi:10.1007/s10551-014-2316-3

Kærgård, N., \& Dalgaard, T. (2016). Dansk landbrugs strukturudvikling siden 2. verdenskrig. Landbohistorisk Tidsskrift, 11(1-2), 9-33.

Lamine, C. (2005). Settling shared uncertainties: Local partnerships between producers and consumers. Sociologia Ruralis, 45(4), 324-345. doi:10.1111/j.1467-9523.2005.00308.x

Laursen, K. B., \& Noe, E. (2017). The hybrid media of economy and moral: A Luhmannian perspective on value-basedfood-chains. Journal of Rural Studies, 56, 21-29. 
Laursen, K. B., Noe, E., \& Kjeldsen, C. (2015). Full case study report: Gram Slot/Rema1000-Denmark. Retrieved from Organic Eprints http://130.226.173.136/project2/Upload/HealthyGrowth/Document/DK_Gram\%20Rema_Case\%20report.pdf.

MacIntyre, A. C. (1981/2007). After Virtue. A Study in Moral Theory. Notre Dame, Indiana: University of Notre Dame Press.

MacIntyre, A. C. (1999). Dependent rational animals: Why human beings need the virtues. Chicago and La Salle. Illinois: Open Court.

Marsden, T. (2000). Food matters and the matter of food: Towards a new food governance? Sociologia Ruralis, 40(1), 2029. doi:10.1111/1467-9523.00129

Michael, R. T., \& Becker, G. S. (1973). On the new theory of consumer behavior. The Swedish Journal of Economics, 75 (4), 378-396.

Moeller, H.-G. (2017). On second-order observation and genuine pretending: Coming to terms with society. Thesis Eleven, 143(1), 28-43.

Morgan, G. (1986/2006). Images of Organization. Beverly Hill: Sage.

Padel, S., \& Foster, C. (2005). Exploring the gap between attitudes and behaviour: Understanding why consumers buy or do not buy organic food. British Food Journal, 107(8), 606-625.

Piketty, T. (2014). Capital in the 21st Century. Cambridge: The Belknap Press of Harvard University Press.

Renting, H., Marsden, T., \& Banks, J. (2003). Understanding alternative food networks: exploring the role of short food supply chains in rural development. Environment and Planning A, 35(3), 393-411.

Renting, H., Oostindie, H., Laurent, C., Brunori, G., Barjolle, D., Jervell, A., Heinonen, M. (2008). Multifunctionality of agricultural activities, changing rural identities and new institutional arrangements. International Journal of Agricultural Resources, Governance and Ecology, 7(4-5), 361-385.

Renting, H., Schermer, M., \& Rossi, A. (2012). Building food democracy: Exploring civic food networks and newly emerging forms of food citizenship. International Journal of Sociology of Agriculture \& Food, 19(3). 289-307.

Schröder, M. J., \& McEachern, M. G. (2004). Consumer value conflicts surrounding ethical food purchase decisions: a focus on animal welfare. International Journal of Consumer Studies, 28(2), 168-177.

Schumpeter, J. A. (1943/2010). Capitalism, Socialism and Democracy. Oxford: Routledge.

Sennett, R. (2006). The Culture of the New Capitalism: Yale University Press.

Shaw, D., Grehan, E., Shiu, E., Hassan, L., \& Thomson, J. (2005). An exploration of values in ethical consumer decision making. Journal of Consumer Behaviour, 4(3), 185-200.

Shaw, D., McMaster, R., \& Newholm, T. (2015). Care and commitment in ethical consumption: An Exploration of the 'attitude-behaviour gap'. Journal of Business Ethics, 136(2). 251-265.

Shaw, D., Shiu, E., \& Clarke, I. (2000). The contribution of ethical obligation and self-identity to the theory of planned behaviour: An exploration of ethical consumers. Journal of Marketing Management, 16(8), 879-894.

Sløk, C., \& Villadsen, K. (2008). Velfcerdsledelse: Ledelse og Styring i den Selvstyrende Velfcerdsstat. København: Hans Reitzel.

Standing, G. (2011). The precariat: The new dangerous class. London, New Delhi, New York, Syndey: Bloomsbury Academic.

Standing, G. (2014). A precariat charter: From denizens to citizens. London, New Delhi, New York, Syndey: Bloomsbury Academic.

Szmigin, I., \& Carrigan, M. (2005). Exploring the dimensions of ethical consumption. In K. M. Ekstrom \& H. Brembeck (Eds.), E-European Advances in Consumer Research Volume 7. Goteborg: Association for Consumer Research. 608613.

Taylor, C. (1991). The Ethics of Authenticity. Cambridge, Massachusetts and London, England: Harvard University Press.

Thompson, C. J., \& Coskuner-Balli, G. (2007). Enchanting ethical consumerism the case of community supported agriculture. Journal of Consumer Culture, 7(3), 275-303.

Vermeir, I., \& Verbeke, W. (2006). Sustainable food consumption: Exploring the consumer "attitude-behavioral intention" gap. Journal of Agricultural and Environmental Ethics, 19(2), 169-194.

von Mises, L. (1949/1998). Human action. Auburn: Ludwig von Mises Institute. 
Willmott, H. (1993). Strength is ignorance; slavery is freedom: managing culture in modern organizations. Journal of Management Studies, 30(4), 515-552.

Winter, M. (2003). Embeddedness, the new food economy and defensive localism. Journal of Rural Studies, 19(1), $23-32$. doi:http://dx.doi.org/10.1016/S0743-0167(02)00053-0

i Denmark is one of the countries with the highest percentage of the population on Facebook, leaving many businesses to rely heavily on this form of communication. 